\title{
Treatment Efficiency and Characteristics of Biomass in a Full-Scale Wastewater Treatment Plant with Aerobic Granular Sludge
}

\author{
Agnieszka Cydzik-Kwiatkowska ${ }^{* *}$, Michał Podlasek', Dawid Nosek', Beata Jaskulska' \\ 1 University of Warmia and Mazury in Olsztyn, Department of Environmental Biotechnology, Słoneczna 45G, \\ 10-709 Olsztyn, Poland \\ *Corresponding author's e-mail: agnieszka.cydzik@uwm.edu.pl
}

\begin{abstract}
Recently, studies have been carried out on an implementation of aerobic granular sludge (AGS) technology in fullscale wastewater treatment plants. The aim of the work was to evaluate the effectiveness of organic, phosphorus and nitrogen compounds removal from municipal wastewater and to characterize the biomass in a wastewater treatment plant upgraded from the activated sludge to AGS technology. In the upgraded facility, granulation was obtained quickly and it was observed that the granule morphology depended of the temperature. In the granular biomass harvested at moderate temperatures in the reactor $\left(15^{\circ} \mathrm{C}\right)$, the granules with diameters in the range from 125 to $500 \mu \mathrm{m}$ constituted the largest share (about $60 \%$ ), while the second-largest biomass fraction comprised the granules with diameters over $1 \mathrm{~mm}(25 \%)$. The analysis of granule diameters carried out in winter (the temperature in the reactor equaled $8^{\circ} \mathrm{C}$ ) showed a decrease in the share of the largest granules and predominance of the granules with diameters in the range from 90 to $355 \mu \mathrm{m}$ (about 75\%). Upgrading the municipal wastewater treatment plant from activated sludge to aerobic granular sludge significantly improved the settling properties of the biomass and efficiency of wastewater treatment. The average efficiency chemical oxygen demand (COD) and phosphorus removal increased by about $10 \%$ and $20 \%$, respectively, while ammonium nitrogen was completely oxidized, regardless of the season. After modernization, the concentration of nitrates in the effluent increased significantly to about $3-6 \mathrm{mg} / \mathrm{L}$. The results of the study show that it is possible to effectively upgrade the existing facilities to aerobic granular sludge technology; it was also proven that this technology is an excellent alternative to a conventional activated sludge.
\end{abstract}

Keywords: next-generation sequencing, microbial structure, full-scale wastewater treatment plant, wet sieving, wastewater temperature, aerobic granules

\section{INTRODUCTION}

Microorganisms in the form of biofilm, activated sludge flocs or granules are commonly used in the aerobic and anaerobic wastewater treatment systems. The use of aerobic granules for wastewater treatment is a relatively new technological solution, intensively implemented at the technical scale, both in in Poland [Świątczak, Cydzik-Kwiatkowska 2017, Podlasek et al. 2017] as well as worldwide [van der Roest et al. 2011, Giesen et al. 2013].

Wastewater treatment in batch reactors based on aerobic granular sludge does not require de- signing the multi-reactor treatment line and the reactor working cycle is much shorter. The presence of anaerobic zones in the granules allows the removal of nitrogen and phosphorus without the need to provide anaerobic conditions in the reaction chamber, while the very good settling properties of the granules allow to reduce the length of a settling phase [Sławiński 2015]. The absence of a conventional recirculation pump and stirrers ensures a significant reduction in the energy consumption, compared to the conventional wastewater treatment plants [de Kreuk et al. 2005a].

The world's first pilot-scale system with granular sludge treating municipal wastewater 
was launched in 2003 in the Netherlands. It consisted of two biological reactors with a height and diameter of $6 \mathrm{~m}$ and $0.6 \mathrm{~m}$, respectively, working in parallel [de Kreuk 2006]. The world's first full-scale municipal wastewater treatment plant (WWTP) based on the aerobic granular sludge technology was built in Gansbaai (South Africa). The treatment plant was designed with a capacity of $4,000 \mathrm{~m}^{3} / \mathrm{d}$ and consisted of three reactors operated in parallel [Li et al. 2014]. In Poland, experience indicates that upgrading existing activated sludge WWTPs to granular sludge technology substantially improved COD, phosphorus and nitrogen removal, as well as reducing the volume of the biological reactors by $30 \%$ [Świątczak, Cydzik-Kwiatkowska 2017]

The study of microorganisms in a WWTP provides information on the species structure of the community, indicating the dominant microbiological groups responsible for effective wastewater treatment. The discoveries made in recent years have enabled the introduction of next-generation sequencing (NGS), which is regarded as the most suitable method for studying complex microbial consortia [Kotowska, Zakrzewska-Czerwińska 2010].

Wastewater treatment is characterized by the trophic relationships typical to the detritus chain. Microorganisms oxidize organic matter, transform food substrates, and produce polysaccharides and other polymers [Tarczewska 1997]. The basic genera found in the activated sludge systems are Zooglea, Flavobacterium, Alcaligenes, Bacillus, Achromobacter, Corynobacterium, Comomonas, Brevibacterium and Acinetobacter [Bitton 2005]. Aerobic granules have a layered structure; in the outer layer, which is directly in contact with wastewater, nitrifying microorganisms dominate, while denitrifiers and bacteria accumulating polyphosphates are located in the center of the granules. A high proportion of microorganisms capable of producing extracellular polymeric substances (EPS) in the biomass is favorable for the stability of the granule structure.

To date, despite the growing interest in the implementation of aerobic granular sludge technology, limited data on the treatment efficiency and biomass structure in such full-scale WWTPs has been presented in the literature. The aim of the work was to assess the effectiveness of pollutant removal and the characteristics of biomass in a full-scale WWTP upgraded from activated sludge to aerobic granular sludge technology.

\section{MATERIALS AND METHODS}

\section{Technological studies}

The effectiveness of municipal wastewater treatment after upgrading to aerobic granular sludge technology was investigated from September 2014 to June 2016 at WWTP in Jeziorany (Poland). Municipal wastewater (about $500 \mathrm{~m}^{3} / \mathrm{d}$ ) and the wastewater from a meat processing plant (about $510 \mathrm{~m}^{3} / \mathrm{month}$ ) were supplied to the treatment plant. The characteristics of wastewater in the investigated period were as follows: total suspended solids (TSS) $0.340 \mathrm{~g} / \mathrm{L}$, total Kjeldahl nitrogen (TKN) $0.110 \mathrm{~g} / \mathrm{L}$, total phosphorus (TP) $0.021 \mathrm{~g} / \mathrm{L}, 1.431 \mathrm{~g} \mathrm{COD} / \mathrm{L}$. The technological line included a horizontal grate, a vertical vortex grate, a stepped mechanical grate, a retention tank and a batch granular sludge reactor (GSBR). The excess sludge was directed to the thickener and then to the aerobic stabilization tank. From the GSBR, the wastewater flowed to the secondary settling tank. The sludge from the secondary settling tank was recycled to the aerobic stabilization tank, and the treated wastewater was discharged to the river.

After the upgrading of WWTP to the aerobic granular sludge technology, the GSBR was operated at a hydraulic sewage retention time of $31 \mathrm{~h}$, the organic load of at the beginning of the GSBR cycle of $1.1 \mathrm{~kg} \mathrm{COD} /\left(\mathrm{m}^{3} \cdot \mathrm{d}\right)$ and sludge age of $28 \mathrm{~d}$. The average biomass concentration was $4.8 \mathrm{~g} \mathrm{MLSS} / \mathrm{L}$.

In the influent and effluent, COD, ammonium nitrogen, nitrates and nitrites were analyzed according to APHA (1992). In the GSBR, the concentration of mixed liquor suspended solids (MLSS) and the sludge volumetric index (SVI) after 30 min of settling were measured [APHA 1992]. The morphology of the granules was evaluated using wet sieving in an AS 200 screening unit (Retsch Sieves with mesh sizes of $2 \mathrm{~mm}, 1$ $\mathrm{mm}, 710 \mu \mathrm{m}, 500 \mu \mathrm{m}, 355 \mu \mathrm{m}, 125 \mu \mathrm{m}$ and 90 $\mu \mathrm{m}$ were used for the analysis. During the analysis, the sludge was washed with tap water $\left(12^{\circ} \mathrm{C}\right)$ from the spray nozzle over the uppermost sieve; the sieving lasted for $10 \mathrm{~min}$ and the vibration amplitude was $50 \mathrm{~mm}$. The granule photographs were taken with a fluorescence microscope Eclipse 50i (Nikon).

\section{Molecular research}

The biomass samples were collected in October 2014, August 2015 and October 2015. DNA 
isolation was performed from $200 \mu 1$ of centrifuged sludge (8000 rpm, 2 min) using a FastDNA ${ }^{\circledR}$ SPIN Kit for Soil (MP Biomedicals). The quality and quantity of the DNA was assessed in a NanoDrop Lite spectrophotometer (Thermo Scientific) at 260 and $280 \mathrm{~nm}$. The isolated DNA was sent to the Research and Testing Laboratory (USA) for high-throughput sequencing. A primer set $357 \mathrm{wF} / 785 \mathrm{R} \quad(357 \mathrm{wF}$ 5'CCTACGGGNGGCWGCAG 3'; 785R 5 ,GACTACHVGGGTATCTAATCC 3') was used to amplify the $16 \mathrm{~S}$ rDNA gene [Wu et al. 2016]. The data processing was conducted according to the methodology from the Research and Testing Laboratory (http:// www.researchandtesting.com/docs/Data_Analysis_Methodology.pdf).

\section{Statistics}

The results were analyzed with Statistica 12.5 software (StatSoft). In order to compare the two samples, a t-test for independent samples was used after normality and homogeneity of variance were confirmed with the Shapiro-Wilk test and Levene's test. With all tests, $\mathrm{p}<0.05$ was considered significant.

\section{RESULTS}

During the GSBR working cycle, the contents of the reactor were constantly aerated. In the first 38 minutes of the cycle, the oxygen concentration increased to a maximum value of $4.5 \mathrm{mg} / \mathrm{L}$ (Fig. 1). After a further 37 minutes, the oxygen concentration dropped to the smallest value of $0.96 \mathrm{mg} / \mathrm{L}$, and then gradually increased for about 2 hours to about $2.5 \mathrm{mg} / \mathrm{L}$ at the end of the aeration phase.
Before the upgrading of the sewage treatment plant, the SVI was in the range of $130-170 \mathrm{~mL} / \mathrm{g}$ MLSS, whereas after the introduction of the aerobic granular sludge, the SVI fell below $50 \mathrm{~mL} / \mathrm{g}$ MLSS. The microscopic analysis showed that after granulation, dense, spherical microbial consortia were present in the biomass (Fig. 2).

Wet sieving of granular sludge from WWTP was carried out in November 2015 and in February 2016. During the first analysis, the granules with a diameter ranging from $125 \mu \mathrm{m}$ to $500 \mu \mathrm{m}$ comprised the largest share of the granular biomass (about 60\%) (Fig. 3a). The second largest component of biomass included the granules with a diameter of more than $1 \mathrm{~mm}(25 \%)$. In the sieve analysis conducted in February 2016, the share of the two largest fractions was lower than in November 2015 (Fig. 3b) and smaller granules predominated in the biomass.

The change from activated sludge to granular sludge significantly increased the efficiency of pollutant removal. The average efficiency of COD removal increased by about $10 \%$ to $95 \%$, while the average efficiency of phosphorus removal increased by about $20 \%$ to about $30 \%$. The average concentration of ammonium nitrogen in the effluent was high (40 mg/L), which corresponded to a nitrification efficiency of $48.5 \pm 6.7 \%$. After upgrading, ammonium nitrogen was completely removed (Fig. 4a), and the average nitrification efficiency increased to $99.8 \pm 0.57 \%$.

The concentration of nitrates in the effluent after upgrading (from October 2014) was maintained at an average of $3.7 \pm 1.5 \mathrm{mg} / \mathrm{L}$ (Fig. $4 \mathrm{~b}$ ), which was significantly higher than before modernization $(0.4 \pm 0.3 \mathrm{mg} / \mathrm{L})$. In the winter periods, higher concentrations of nitrate nitrogen $(\mathrm{V})$ in

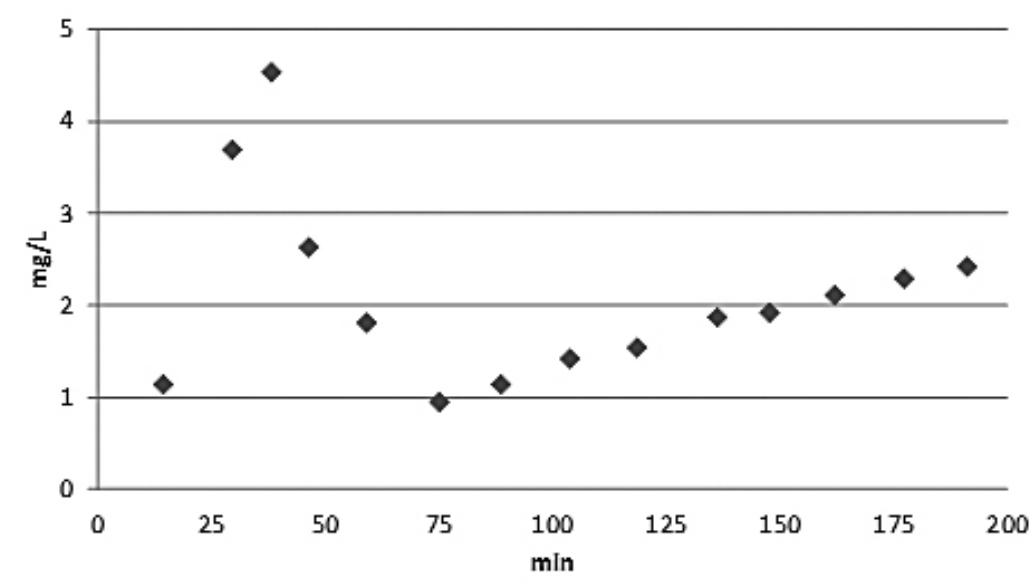

Fig. 1. Oxygen concentration changes in a working cycle of granular sequencing batch reactor 



Fig. 2. Aerobic granules from wastewater treatment plant in Jeziorany

a)

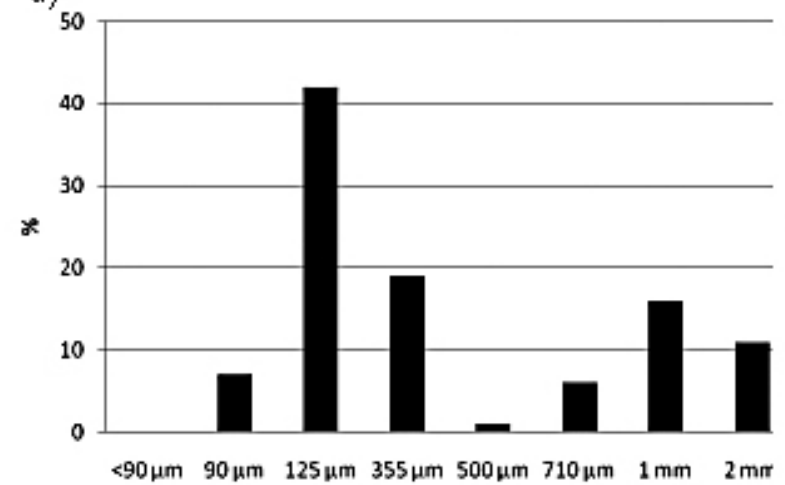

b)

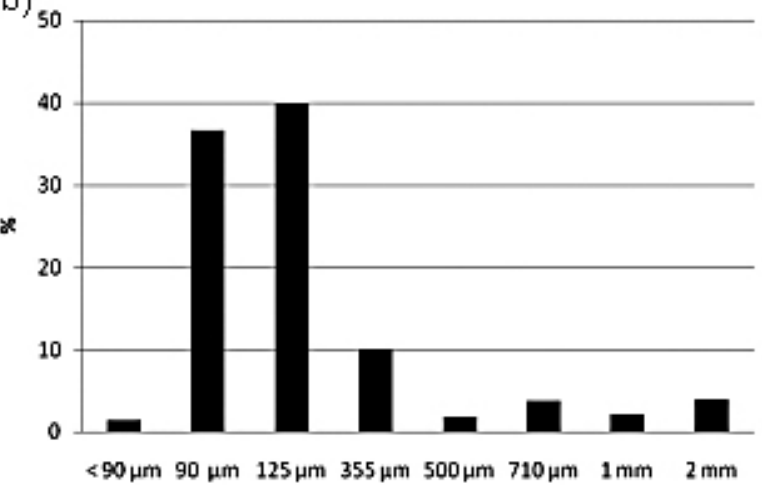

Fig. 3. Results of wet sieving analysis a) November 2015, b) February 2016; sieves with hole sizes of 2 mm, 1 $\mathrm{mm}, 710 \mu \mathrm{m}, 500 \mu \mathrm{m}, 335 \mu \mathrm{m}, 125 \mu \mathrm{m}$ and $90 \mu \mathrm{m}$ were used

the outflow were recorded, which indicated a decrease in denitrification efficiency.

The samples for molecular tests were collected in $1^{\text {st }}, 1368^{\text {th }}$ and $1643^{\text {rd }}$ cycle of reactor operation, when the temperature in the aeration chamber was $16.0,22.5$ and $16.0^{\circ} \mathrm{C}$, respectively. Archaea and Bacteria were present in the biomass, with Bacteria accounting for over $98 \%$ of the sequences. Out of the 43 identified classes of microorganisms, the most numerous were Actinobacteria $\left(36.9 \%, 25.2 \%, 22.3 \%\right.$ in $1^{\text {st }}, 1368^{\text {th }}$ and $1643^{\text {rd }}$ cycle of reactor operation, respectively), Alphaproteobacteria $(13.8 \%, 15.4 \%, 13.3 \%)$, Betaproteobacteria $(7.8 \%, 15.6 \%, 16.1 \%)$, and Gammaproteobacteria $(11.2 \%, 14.3 \%, 10.0 \%)$. In total, 79 orders were identified in the analyzed biomass, the most numerous orders were Actinomycetales $(11.8 \%, 26.9 \%, 1.7 \%)$, Xanthomondales $(5.0 \%$, 10.2\%, 5.0\%), Rhizobiales (5.9\% 6.7\% 3.30\%), Burkholderiales $(7.5 \%, 8.4 \%, 8.5 \%)$, Rhodocyclales $(0.5 \%, 5.3 \%, 6.0 \%)$ and Lactobacillales $(1.4 \%, 4.5 \%, 2.0 \%)$.
In Table 1, the genera of microorganisms with abundances in biomass higher than $1 \%$ are presented. The most numerous microorganisms belonged to the genera Acidothermus (3.85\%, $3.70 \%, 4.82 \%)$, Tetrasphaera $(4.22 \%, 3.63 \%$, 5.44\%), Trichococcus (4.27\% $1.33 \% \quad 1.82 \%)$, Clostridium (2.57\%, 1.38\%, 0.63\%), Mesorhizobium $(2.14 \%, 1.53 \%, 0.25 \%)$ and Acidovorax $(3.25 \%, 2.51 \%, 1.40 \%)$.

\section{DISCUSSION}

The study was conducted in a municipal wastewater treatment plant in Jeziorany - one of the first full-scale WWTPs with aerobic granules in Poland.

The SVI for aerobic granular sludge should not exceed $50 \mathrm{~mL} / \mathrm{g}$ MLSS [Toh et al. 2003]. In this study, after WWTP upgrading, the SVI of the biomass was below $50 \mathrm{~mL} / \mathrm{g}$ MLSS and the settling properties were significantly improved. 
a)

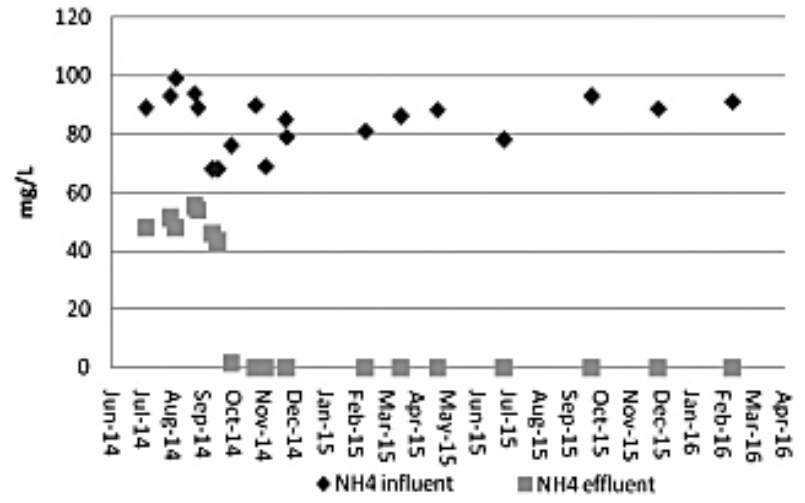

b)

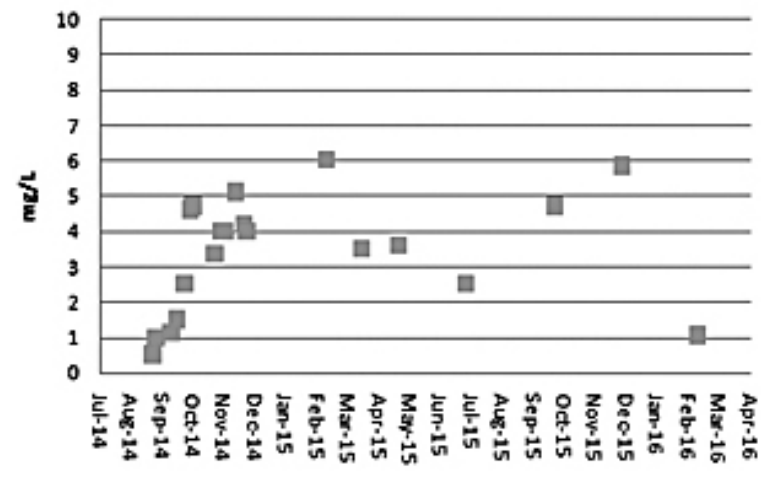

Fig. 4. Concentration of a) ammonium nitrogen in the influent and in the effluent, b) nitrates in the effluent

For comparison, the SVI values at the Yancang WWTP decreased after the introduction of granular sludge technology from 75.5 to $43 \mathrm{~mL} / \mathrm{g}$ MLSS after 14 days of operation. Over the next 310 days, the average value of SVI stabilized at $48 \mathrm{~mL} / \mathrm{g}$ MLSS [Li et al. 2014]. The concentration of the granular biomass in full-scale reactors can reach up to $9 \mathrm{~g}$ MLSS/L [Pronk et al. 2015]. In the present study, the concentration of the MLSS in the batch reactor averaged $4.8 \mathrm{~g} \mathrm{MLSS} / \mathrm{L}$, while the concentration of total suspended solids in the effluent was below $25 \mathrm{mg} / \mathrm{L}$.

Upgrading the investigated WWTP improved the efficiency of organic compounds removal; before modernization, the efficiency of COD removal did not exceed $90 \%$, while after modernization it reached $95 \%$. The obtained efficiency was higher than in other aerobic granular sludge WWTPs. In the Yancang WWTP, treating a mixture of domestic and industrial wastewater (dyeing, textile and food industry) $(3: 7 \mathrm{v} / \mathrm{v})$ with a concentration of 200-600 $\mathrm{mg} \mathrm{O}_{2} / \mathrm{L}$, the efficiency of COD removal by aerobic granules was $85 \%$ [Li et al. 2014]. Pronk and others (2015) studied the effectiveness of municipal wastewater treatment (506 mg COD/L, $6.7 \mathrm{mg} \mathrm{TP} / \mathrm{L}, 49 \mathrm{mg}$ TKN/L) at the WWTP in Garmerwolde. The reactors with granular sludge were operated at the sludge age of 20-38 d and theMLSS concentration in the aeration chamber of $6.5-8.5 \mathrm{~g} / \mathrm{L}$. Under these operating conditions, the authors observed the effectiveness of COD removal of about $87 \%$. In the tested WWTP, after upgrading, full ammonium nitrogen removal was observed. Similar results were observed at the Yancang and Garmerwolde WWTPs, where the ammonium removal efficiency was $96 \%$ and $97 \%$, respectively [Li et al. 2014, Pronk et al 2015]. In addition, the
Yancang plant had a high efficiency of total nitrogen removal of $60 \%$ [Li et al 2014].

According to the literature, the size of the granules ranges from $0.2 \mathrm{~mm}$ to $9.0 \mathrm{~mm}$. An increase in the granule diameter may cause problems with proper operation of the batch reactor [Liu, Tay 2004, Cydzik-Kwiatkowska et al. 2009]. During the first analysis of granule morphology in this study, it was observed that $25 \%$ of the biomass consisted of granules with a diameter above $1 \mathrm{~mm}$, while the granules with a diameter of $125-500 \mu \mathrm{m}$ consituted $60 \%$. At the second measurement, the share of granules with diameters higher than $1 \mathrm{~mm}$ was much lower. The differences between the sizes of granules at both measurements resulted from the changes in the operating temperature of the GSBR. The first analysis was carried out at a wastewater temperature of around $15^{\circ} \mathrm{C}$, and the second was carried out at a temperature of $8^{\circ} \mathrm{C}$. According to de Kreuk et al. (2005b), the start-up of the treatment plant with aerobic granular sludge at $8^{\circ} \mathrm{C}$ resulted in the production of irregularly shaped granules, which caused the biomass washout from the system and unstable operation. Starting-up the granular reactors at $20^{\circ} \mathrm{C}$, and then reducing the temperature to $15^{\circ} \mathrm{C}$ and $8^{\circ} \mathrm{C}$, did not significantly affect the stability of the granules and biomass was effectively retained in the technological system. Our own experiments indicate that the start-up of an aerobic granular sludge system during the summer period ensures stable granulation and effective organics, nitrogen and phosphorus removal even during winter.

In the aerobic granules from the full-scale WWTP in the present study, the bacteria belonging to Proteobacteria and Actinobacteria predominated. Alphaproteobacteria, Betaproteobacteria, Gammaproteobacteria and Actinobacteria accounted for between 7.8 and $36.9 \%$ of the microor- 
Tab.1. Genera of microorganisms present in aerobic granules ( $\%$ of all sequences)

\begin{tabular}{|c|c|c|c|}
\hline Kingdom ; phylum ; class ; order ; family ; genus & $\begin{array}{l}\text { October } \\
2014\end{array}$ & $\begin{array}{l}\text { August } \\
2015\end{array}$ & $\begin{array}{l}\text { October } \\
2015\end{array}$ \\
\hline $\begin{array}{l}\text { Bacteria ; Actinobacteria ; Actinobacteria ; Acidimicrobiales ; Acidimicrobiaceae ; } \\
\text { Aciditerrimonas }\end{array}$ & 0.98 & 0.90 & 0.01 \\
\hline $\begin{array}{l}\text { Bacteria ; Actinobacteria ; Actinobacteria ; Acidothermales ; Acidothermaceae ; } \\
\text { Acidothermus }\end{array}$ & 3.85 & 3.70 & 4.82 \\
\hline $\begin{array}{l}\text { Bacteria ; Actinobacteria ; Actinobacteria ; Actinomycetales ; Actinomycetaceae ; } \\
\text { Actinomyces }\end{array}$ & 1.09 & 0.23 & 0.78 \\
\hline $\begin{array}{l}\text { Bacteria ; Actinobacteria ; Actinobacteria ; Actinomycetales ; Intrasporangiaceae ; } \\
\text { Tetrasphaera }\end{array}$ & 4.22 & 3.63 & 5.44 \\
\hline $\begin{array}{l}\text { Bacteria ; Actinobacteria ; Actinobacteria ; Actinomycetales ; Microbacteriaceae ; } \\
\text { Frigoribacterium }\end{array}$ & 2.5 & 0.76 & 0.12 \\
\hline $\begin{array}{l}\text { Bacteria ; Actinobacteria ; Actinobacteria ; Actinomycetales ; Mycobacteriaceae ; } \\
\text { Mycobacterium }\end{array}$ & 0.91 & 2.65 & 1.33 \\
\hline Bacteria ; Actinobacteria ; Actinobacteria ; Actinomycetales ; Dietziaceae ; Dietzia & 0.05 & 2.84 & 0.06 \\
\hline $\begin{array}{l}\text { Bacteria ; Actinobacteria ; Actinobacteria ; Actinomycetales ; Nocardioidaceae ; } \\
\text { Nocardioides }\end{array}$ & 1.19 & 1.42 & 0.53 \\
\hline $\begin{array}{l}\text { Bacteria; Actinobacteria ; Actinobacteria ; Unclassified ; Unclassified ; Candidatus } \\
\text { Microthrix }\end{array}$ & 3.70 & 0.96 & 0.00 \\
\hline Bacteria ; Chloroflexi ; Caldilineae ; Caldilineales ; Caldilineaceae ; Caldilinea & 1.18 & 1.98 & 0.58 \\
\hline Bacteria ; Firmicutes ; Bacilli ;Lactobacillales; Carnobacteriaceae ; Trichococcus & 4.27 & 1.33 & 1.82 \\
\hline Bacteria ; Firmicutes ; Clostridia ; Clostridiales ; Clostridiaceae ; Clostridium & 2.57 & 1.38 & 0.63 \\
\hline $\begin{array}{l}\text { Bacteria ; Proteobacteria ; Alphaproteobacteria ; Caulobacterales ; Caulobacteraceae ; } \\
\text { Phenylobacterium }\end{array}$ & 1.38 & 0.61 & 0.00 \\
\hline $\begin{array}{l}\text { Bacteria ; Proteobacteria ; Alphaproteobacteria ; Rhizobiales ; Hyphomicrobiaceae ; } \\
\text { Devosia }\end{array}$ & 0.68 & 1.49 & 0.55 \\
\hline $\begin{array}{l}\text { Bacteria ; Proteobacteria ; Alphaproteobacteria ; Rhizobiales ; Phyllobacteriaceae ; } \\
\text { Mesorhizobium }\end{array}$ & 2.14 & 1.53 & 0.25 \\
\hline Bacteria ; Proteobacteria ; Alphaproteobacteria ; Rhizobiales ; Rhizobiaceae ; Rhizobium & 0.53 & 0.71 & 1.07 \\
\hline $\begin{array}{l}\text { Bacteria ; Proteobacteria ; Alphaproteobacteria ; Rhodobacterales ; Rhodobacteraceae ; } \\
\text { Gemmobacter }\end{array}$ & 1.48 & 0.38 & 0.00 \\
\hline $\begin{array}{l}\text { Bacteria ; Proteobacteria ; Alphaproteobacteria ; Rhodobacterales ; Rhodobacteraceae ; } \\
\text { Paracoccus }\end{array}$ & 1.54 & 0.75 & 0.34 \\
\hline $\begin{array}{l}\text { Bacteria ; Proteobacteria ; Alphaproteobacteria ; Rhodospirillales ; Acetobacteraceae ; } \\
\text { Roseomonas }\end{array}$ & 1.17 & 0.81 & 0.19 \\
\hline $\begin{array}{l}\text { Bacteria ; Proteobacteria ; Alphaproteobacteria ; Rhodospirillales ; Rhodospirillaceae ; } \\
\text { Dongia }\end{array}$ & 0.04 & 0.68 & 1.19 \\
\hline $\begin{array}{l}\text { Bacteria ; Proteobacteria ; Alphaproteobacteria ; Sphingomonadales ; } \\
\text { Sphingomonadaceae ; Sphingobium }\end{array}$ & 1.12 & 0.51 & 0.27 \\
\hline $\begin{array}{l}\text { Bacteria; Proteobacteria ; Alphaproteobacteria ; Sphingomonadales ; } \\
\text { Sphingomonadaceae ; Sphingopyxis }\end{array}$ & 0.03 & 0.80 & 4.40 \\
\hline $\begin{array}{l}\text { Bacteria ; Proteobacteria ; Betaproteobacteria ; Burkholderiales ; Comamonadaceae ; } \\
\text { Acidovorax }\end{array}$ & 3.25 & 2.51 & 1.40 \\
\hline $\begin{array}{l}\text { Bacteria; Proteobacteria ; Betaproteobacteria ; Burkholderiales ; Comamonadaceae ; } \\
\text { Rhodoferax }\end{array}$ & 0.15 & 2.02 & 1.51 \\
\hline $\begin{array}{l}\text { Bacteria ; Proteobacteria ; Betaproteobacteria ; Burkholderiales ; Comamonadaceae ; } \\
\text { Simplicispira }\end{array}$ & 1.13 & 0.07 & 0.00 \\
\hline Bacteria ; Proteobacteria ; Betaproteobacteria ; Burkholderiales ; Unclassified ; Leptothrix & 0.37 & 1.34 & 1.34 \\
\hline $\begin{array}{l}\text { Bacteria ; Proteobacteria ; Betaproteobacteria ; Rhodocyclales ; Rhodocyclaceae ; } \\
\text { Dechloromonas }\end{array}$ & 0.16 & 0.86 & 1.73 \\
\hline $\begin{array}{l}\text { Bacteria ; Proteobacteria ; Betaproteobacteria ; Rhodocyclales ; Rhodocyclaceae ; } \\
\text { Thauera }\end{array}$ & 0.04 & 1.35 & 0.63 \\
\hline $\begin{array}{l}\text { Bacteria ; Proteobacteria ; Betaproteobacteria ; Rhodocyclales ; Rhodocyclaceae ; } \\
\text { Zoogloea }\end{array}$ & 0.01 & 1.7 & 0.90 \\
\hline $\begin{array}{l}\text { Bacteria ; Proteobacteria ; Gammaproteobacteria ; Oceanospirillales ; Halomonadaceae ; } \\
\text { Halomonas }\end{array}$ & 0.00 & 0.00 & 1.90 \\
\hline $\begin{array}{l}\text { Bacteria ; Proteobacteria ; Gammaproteobacteria ; Pseudomonadales ; } \\
\text { Pseudomonadaceae ; Pseudomonas }\end{array}$ & 1.10 & 1.15 & 1.46 \\
\hline $\begin{array}{l}\text { Bacteria ; Proteobacteria ; Gammaproteobacteria ; Xanthomonadales ; } \\
\text { Rhodanobacteraceae ; Dokdonella }\end{array}$ & 0.75 & 1.62 & 0.81 \\
\hline $\begin{array}{l}\text { Bacteria ; Proteobacteria ; Gammaproteobacteria ; Xanthomonadales ; } \\
\text { Xanthomonadaceae ; Aquimonas }\end{array}$ & 0.04 & 1.31 & 0.41 \\
\hline $\begin{array}{l}\text { Bacteria ; Proteobacteria ; Gammaproteobacteria ; Xanthomonadales ; } \\
\text { Rhodanobacteraceae ; Rhodanobacter }\end{array}$ & 0.06 & 1.60 & 1.34 \\
\hline $\begin{array}{l}\text { Bacteria ; Proteobacteria ; Gammaproteobacteria ; Xanthomonadales ; } \\
\text { Xanthomonadaceae ; Thermomonas }\end{array}$ & 1.70 & 2.31 & 1.27 \\
\hline Unrecognized & 1.53 & 2.23 & 1.68 \\
\hline
\end{tabular}


ganisms in aerobic granules, which indicated that they were necessary for the proper formation of the granule structure and played an important role in the transformation of nutrients in wastewater.

The species structure of the bacterial community changed with maturation of the granular biomass. In the initial stages of granulation, filamentous microorganisms serve as a frame upon which single cells of bacteria are deposited [Cydzik-Kwiatkowska 2014]. In the tested samples, the number of the filamentous bacteria of the genus Microthrix was high in the initial working cycles $(3.70 \%)$, when the reactor was dominated by the activated sludge. As mature aerobic granules were formed, the number of Microthrix sp. decreased until they completely disappeared in the biomass after about 1,600 GSBR working cycles.

In the granular biomass, numerous microorganisms involved in the transformation of carbon and nitrogen compounds were identified. Tetrasphaera sp., which are responsible for denitrification and accumulation of polyphosphates, constituted up to $5.44 \%$ of the species identified in mature granules. The abundance of Tetrasphaera was high throughout the study which suggested that their presence was not determined by the type of biomass in the biological reactor (activated sludge vs. granular sludge). Muszyński and Załęska-Radziwiłł (2015) observed that the phosphate-cumulating microorganisms comprised from 18 to $36 \%$ of all bacteria and most of them belonged to Tetrasphaera sp. Their highest abundance was observed in WWTPs with high participation of wastewater from food industry $\left(\mathrm{BOD}_{5}\right.$ at a level of thousands of $\left.\mathrm{mg} / \mathrm{L}\right)$. In the present study, the wastewater from a meat processing plant was regularly discharged to the treatment plant that probably favored growth of Tetrasphaera sp. On the other hand, Clostridium sp., which are able to decompose organic substances, constituted $2.57 \%$ of the identified species at the beginning of the study but their abundance decreased with granule maturation to $0.63 \%$ at the end of the study.

Other denitrifying bacteria were Thauera sp., whose percentage in the biomass reached $1.35 \%$. This group of microorganisms has the ability to metabolize organic compounds under the aerobic and anoxic conditions and is also commonly found in technological systems with activated sludge [Liu et al. 2006]. The changes of biomass morphology from loose activated sludge flocs to densely packed spherical granules diminished the abundance of aerobic denitrifiers belonging to Mesorhizobium sp. from 2.14 to $0.25 \%$.
EPS have a significant contribution to the phenomenon of microbial adhesion as well as to the mechanical strength of granules. Extracellular polymers favor fast adaptation of microorganisms to the environmental conditions and support the formation of three-dimensional, heterogeneous bacterial structures in wastewater treatment systems. In aerobic granules, the bacteria of Rhizobium genus, which have denitrification genes and are able to produce polysaccharides that are part of EPS, were identified. Another EPS-producer capable of dissimilatory reduction of nitrate nitrogen (III) [Adav et al. 2008] that was identified in the biomass was Pseudomonas sp.

Observations indicate that the temperature of wastewater treatment affects the removal of nitrogen by aerobic granules [de Kreuk et al. 2005b], whereas it does not significantly affect the efficiency of phosphorus removal [Bao et al. 2009]. The present study indicates that the temperature also affects the microbial structure of granules: the highest species diversity (data not presented) was observed in the granular biomass in summer. During this period, the highest percentages of microorganisms from the genera Thermomonas, Dietzia, Rhodobacter, Dokdonella and Dyella were observed.

\section{CONCLUSIONS}

The results of this study indicate that the aerobic granular sludge is an excellent alternative to the conventional activated sludge. Upgrading a WWTP to the aerobic granular sludge technology improved the quality of the treated wastewater: the COD removal efficiency was about $10 \%$ higher and ammonium nitrogen was completely oxidized. The use of aerobic granules for the treatment of municipal wastewater in a moderate climate ensured the maintenance of the required quality of the effluent throughout the year, although the temperature affected the morphology of the aerobic granules. In the aerobic granules, the most numerous group of microorganisms were the bacteria from the Actinobacteria class. At higher temperatures in the granules, the percentage of microorganisms from the genus Rhodobacter, Dietzia and Dyella increased, whereas the bacteria from genera like Sphingopyxis, Dechloromonas or Halomonas were most abundant in the mature aerobic granules collected from the biological reactor at the end of the study. Granulation resulted in the disappearance of the filamentous microorganisms of the Microthrix genus from the biomass. 


\section{Acknowledgements}

This study was supported by the Polish National Science Center (grant number 2016/21/B/ NZ9/03627) and by a Ministry of Science and Higher Education in Poland (Statutory Research, 18.610.006-300).

\section{REFERENCES}

1. Adav S.S., Lee D.J., Show K.Y., Tay J.H. 2008. Aerobic granular sludge: recent advances. Biotechnology Advances, 26, 411-423.

2. APHA Standard Methods for the Examination of Water and Wastewater (1992). 18th edn. APHA, AWWA and WEF, Washington.

3. Bao R., Yu S., Shi W., Zhang X., Wang Y. 2009. Aerobic granules formation and nutrients removal characteristics in sequencing batch airlift reactor (SBAR) at low temperature. Journal of Hazardous Materials, 168, 1334-1340.

4. Bitton G. 2005. Wastewater Microbiology. A John Wiley \& Sons, Inc. Publication, 225-235.

5. Cydzik-Kwiatkowska A. 2014. Zastosowanie oraz perspektywy rozwoju technologii granulacji tlenowej w oczyszczaniu ścieków. Inżynieria Ekologiczna, 38, 156-166.

6. Cydzik-Kwiatkowska A., Białowiec A., Wojnowska-Baryła I., Smoczyński L. 2009. Characteristic of granulated activated sludge fed with glycerin fraction from biodiesel production. Archives of Environmental Protection, 35, 41-52.

7. Cydzik-Kwiatkowska A., Zielińska M. Technologia osadu granulowanego w oczyszczaniu ścieków, in: Trendy w biotechnologii środowiskowej, Ed. Wojnowska-Baryła I., Wydawnictwo Uniwersytetu Warmińsko-Mazurskiego, Olsztyn 2011.

8. de Kreuk M.K. 2006. Aerobic granular sludge: scaling up a new technology. Delft University of Technology, Delft ( $\mathrm{PhD}$ thesis).

9. de Kreuk M.K., McSwain B.S., Bathe S., Tay J., Schwarzenbeck S.T.L., Wilderer P.A. 2005a. Discussion outcomes. Ede. In: Aerobic granular sludge, water and environmental management series. Munich: IWA Publishing, 165-169.

10. de Kreuk M.K., Pronk M., van Loosdrecht M.C. $2005 \mathrm{~b}$. Formation of aerobic granules and conversion processes in an aerobic granular sludge reactor at moderate and low temperatures. Water Research, 39(18), 4476-4484.

11. Giesen A., de Bruin L.M.M., Niermans R.P., van der Roest H.F. 2013. Advancements in the application of aerobic granular biomass technology for sustainable treatment of wastewater. Water Practice Technology, 8(1), 47-54.
12. Kotowska M., Zakrzewska-Czerwińska J. 2010. Kurs szybkiego czytania DNA - nowoczesne techniki sekwencjonowania. Biotechnologia, 4, 24-38.

13. Liu B., Zang F., Feng X., Liu Y., Yan X., Zhang X., Wang L., Zhao L. 2006. Thauera and Azoarcus as functionally important genera in a denitriyfing quinoline-removal bioreactor as revealed by $\mathrm{mi}$ crobial community structure comparsion. FEMS Microbiology Ecology, 55, 274-286.

14. Li J., Ding L.B., Cai A., Huang G.X., Horn H. 2014. Aerobic Sludge Granulation in a Full-Scale Sequencing Batch Reactor. Hindawi Publishing Corporation, Article ID 268789.

15. Liu Y., Tay J.H. 2004. State of the art of biogranulation technology for wastewater treatment. Biotechnology Advances, 22, 533-563.

16. Muszyński A., Załęska-Radziwiłł M. 2015. Polyphosphate accumulating organisms in treatment plants with different wastewater composition. Architecture Civil Engineering Environment, 4, 99-106.

17. Podlasek M., Gudecki M., Cydzik-Kwiatkowska A. 2017. Technologia granul tlenowych alternatywą dla oczyszczalni ścieków. Przegląd komunalny, 2, 48-49.

18. Pronk M., de Kreuk M.K., de Bruin B., Kamminga P., Kleerebezem R., van Loosdrecht M.C.M. 2015. Full scale performance of the aerobic granular sludge process for sewage treatment. Water Research, 84, 207-217.

19. Sławiński J. 2015. Tlenowy granulowany osad czynny. Gaz, Woda i Technika Sanitarna, 9, 342-344.

20. Świątczak P., Cydzik-Kwiatkowska A. 2017. Performance and microbial characteristics of biomass in a full-scale aerobic granular sludge wastewater treatment plant. Environmental Science and Pollution Research, doi: 10.1007/s11356-017-0615-9.

21. Tarczewska T.M. 1997. Biotyczne i abiotyczne uwarunkowania pęcznienia osadu czynnego. Ochrona środowiska, 65, 29-32.

22. Tay S.T.L., Ivanov V., Yi S., Zhuang W.Q., Tay J.H. 2002. Presence of anaerobic Bacteroides in aerobically grown microbial granules. Microbial Ecology, 44, 278-285.

23. Toh S.K., Tay J.H., Moy B.Y.P., Tay S.T.L. 2003. Size-effect on the physical characteristics of the aerobic granule in a SBR. Applied Microbiol and Biotechnology, 60, 687-695.

24. van der Roest H.F., de Bruin L.M.M., Gademan G., Coelho F. 2011. Towards sustainable waste water treatment with Dutch Nereda ${ }^{\circledR}$ technology. Water Practice and Technology, 6(3).

25. Wu B., Li Y., Lim W., Lee S.L., Guo Q., Fane A.G., Liu Y. 2016. Single-stage versus two-stage anaerobic fluidized bed bioreactors in treating municipal wastewater: Performance, foulant characteristics, and microbial community. Chemosphere, 171, 158-167. 